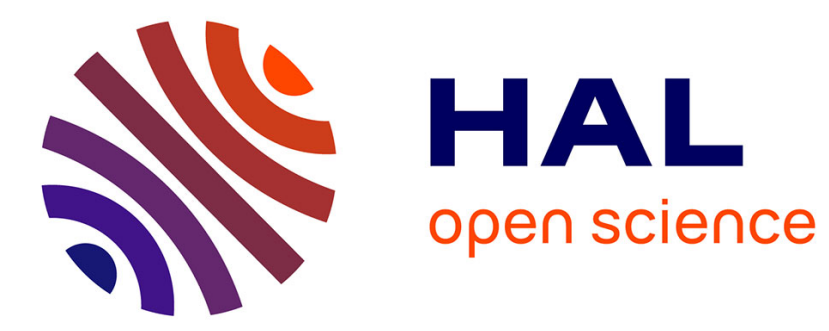

\title{
Plant growth-promoting bacteria as biofertilizer
}

Fauzia Y. Hafeez, Sumera Yasmin, Dini Ariani, Non Renseigné, Yusuf Zafar, Kauser A. Malik

\section{To cite this version:}

Fauzia Y. Hafeez, Sumera Yasmin, Dini Ariani, Non Renseigné, Yusuf Zafar, et al.. Plant growthpromoting bacteria as biofertilizer. Agronomy for Sustainable Development, 2006, 26 (2), pp.143-150. hal-00886338

\section{HAL Id: hal-00886338 https://hal.science/hal-00886338}

Submitted on 1 Jan 2006

HAL is a multi-disciplinary open access archive for the deposit and dissemination of scientific research documents, whether they are published or not. The documents may come from teaching and research institutions in France or abroad, or from public or private research centers.
L'archive ouverte pluridisciplinaire HAL, est destinée au dépôt et à la diffusion de documents scientifiques de niveau recherche, publiés ou non, émanant des établissements d'enseignement et de recherche français ou étrangers, des laboratoires publics ou privés. 
Research article

\title{
Plant growth-promoting bacteria as biofertilizer
}

\author{
Fauzia Y. HAFEEZ ${ }^{*}$, Sumera YASMIN ${ }^{a}$, Dini ARIANI ${ }^{b}$, Mehboob-ur-RAHMAN $^{a}$, Yusuf ZAFAR ${ }^{a}$, Kauser A. MALIK ${ }^{a}$ \\ ${ }^{a}$ National Institute for Biotechnology and Genetic Engineering (NIBGE), PO Box 577, Jhang Road, Faisalabad 38000, Pakistan \\ ${ }^{b}$ R\&D Centre for Biotechnology, The Indonesian Institute of Sciences, JI. Raya Bogor Km 46, Cibinong 16911, Indonesia
}

(Accepted 18 May 2006)

\begin{abstract}
Seventeen rhizobacteria isolated from different ecological regions, i.e. Brazil, Indonesia, Mongolia and Pakistan were studied to develop inoculants for wheat, maize and rice. Almost all the bacterial isolates were Gram-negative, fast-growing motile rods and utilized a wide range of carbon sources. These isolates produced indole-3-acetic acid at concentrations ranging from $0.8-42.1 \mu \mathrm{g} / \mathrm{mL}$, irrespective of the region. Fifteen isolates fixed $\mathrm{N}$ at rates ranging from $20.3-556.8 \mathrm{nmole} \mathrm{C}_{2} \mathrm{H}_{2}$ reduced/h/vial. Isolate $8 \mathrm{~N}-4$ from Mongolia produced the highest amount of indole-3-acetic acid $(42.1 \mu \mathrm{g} / \mathrm{mL})$, produced siderophores $(0.3 \mathrm{mg} / \mathrm{mL})$ and was the only isolate that solubilized phosphate $(188.7 \mu \mathrm{g} \mathrm{P} / \mathrm{mL})$. Inoculation of the wheat variety Orkhon with $8 \mathrm{~N}-4$ isolate resulted in the maximum increase in plant biomass, root length, and total N and $\mathrm{P}$ contents in plants. Random amplified polymorphic deoxyribonucleic acid (RAPD) analysis, conducted with 60 decamer primers, revealed a high level of polymorphism among the bacterial isolates from different geographic regions and a low level of polymorphism among isolates from the same region. The complete 16S rRNA gene sequence analysis demonstrated that $8 \mathrm{~N}-4$ is a Bacillus pumilus strain (Accession number AY548949). It was concluded that Bacillus pumilus $8 \mathrm{~N}-4$ can be used as a bio-inoculant for biofertilizer production to increase the crop yield of wheat variety Orkhon in Mongolia.
\end{abstract}

Rhizobacteria / genetic diversity / RAPD

\section{INTRODUCTION}

Plant growth-promoting bacteria (PGPB) are of great agronomic importance. Indeed, they produce metabolites such as plant growth regulators that directly promote growth and facilitate nutrient uptake by plants (Bai et al., 2002; Salamone et al., 2001). There is widespread distribution of PGPB that flourish in different geographical habitats (Dobereiner et al., 1976; Staley, 1999; Santos et al., 2001).

The large genetic diversity in natural populations of PGPB increases the scope to improve the efficacy of inoculants (Raaijmakers and Weller, 2001). Conventionally, diversity has been assessed by exploring phenotypic and genotypic variation (Hartmann and Amarger, 1991). With the advent of nucleic acid fingerprinting and rRNA sequencing (Bull et al., 1992), it has become possible to distinguish between phenotypically similar strains that are genetically different. These tools provide a more precise way of establishing relationships between many bacterial species (Muyzer and Smalla, 1998).

There is great potential for use of PGPB as biofertilizing agents for a wide variety of crop plants in a wide range of climatic and edaphic conditions (Reed and Glick, 2004). In the present study, rhizobacteria were isolated from Triticum aestivum (wheat), Zea mays (maize) and Oryza sativa (rice) grown in soils of diverse geographical regions and screened for their ability to produce plant growth hormones, solubilize phosphates and fix nitrogen. This investigation was planned as a systematic exploratory study to determine the occurrence of PGPB in soils from Indonesia, Mongolia and Pakistan. An attempt was made to characterize these rhizobacteria and to assess their genetic relatedness using random amplified polymorphic DNA (RAPD) analysis in relation to biochemical and physiological variation of the isolates. The complete $16 \mathrm{~S}$ rRNA gene of a highly promising strain was sequenced for identification purposes. The study will help in developing biofertilizers for cereals with potential benefit to improve the crop productivity.

\section{MATERIALS AND METHODS}

\subsection{Morphological, physiological and biochemical characterization}

\subsubsection{Isolation of bacteria}

Seeds of maize, wheat and rice were surface-sterilized with $0.1 \%$ mercuric chloride for five minutes and then washed three times with sterile water. The sterilized seeds were germinated

*Corresponding author: fauzia_y@yahoo.com, fauzia@nibge.org 
Table I. Indole acetic acid (IAA) production, acetylene reduction assay (ARA) and phosphate solubilization (P) activities of PGPB strains isolated from soils obtained from geographically different regions.

\begin{tabular}{|c|c|c|c|c|c|c|}
\hline Strains & Host & Region & $\begin{array}{c}\text { Tentative } \\
\text { identification }\end{array}$ & $\begin{array}{r}\mathrm{IAA}^{\mathrm{B}} \\
(\mu \mathrm{g} / \mathrm{mL})\end{array}$ & $\begin{array}{c}\text { ARA }^{\mathrm{B}} \\
(\mathrm{nmol} / \mathrm{h} / \text { vial })\end{array}$ & $\begin{array}{c}\mathrm{P}^{\mathrm{B}} \\
(\mu \mathrm{g} / \mathrm{mL})\end{array}$ \\
\hline$\overline{\text { Bt.J No.8 }}$ & Maize & Indonesia & Azospirillum sp. & $19.1 \pm 1$ & $49.5 \pm 0.5$ & $-E$ \\
\hline LS-1 & Maize & Indonesia & Azospirillum sp. & $0.3 \pm 0.6$ & $49.5 \pm 0.5$ & - \\
\hline $07-\mathrm{K}$ & Maize & Indonesia & Azospirillum sp. & $1.9 \pm 0.2$ & $49.2 \pm 0.5$ & - \\
\hline AZ-B & Rice & Indonesia & Azospirillum sp. & $1.4 \pm 0.2$ & $0 \pm 0.1$ & - \\
\hline AZ-S & Rice & Indonesia & Azospirillum sp. & $0.8 \pm 0.2$ & $0 \pm 0.1$ & - \\
\hline $8 \mathrm{~N}-4$ & Wheat & Mongolia & Bacillus sp. & $42.1 \pm 4$ & $20.3 \pm 0.7$ & $188.7 \pm 3$ \\
\hline $8 \mathrm{~N}-2$ & Wheat & Mongolia & Azotobacter sp. & $28.3 \pm 1.6$ & $116.9 \pm 1$ & - \\
\hline $24-\mathrm{N} 2$ & Wheat & Mongolia & Azotobacter sp. & $19.8 \pm 2.1$ & $47.3 \pm 0.6$ & - \\
\hline MST-6.1 & Wheat & Mongolia & Azotobacter sp. & $1.9 \pm 0.1$ & $25.4 \pm 0.5$ & - \\
\hline MST-4.1 & Wheat & Mongolia & Pseudomonas sp. & $37.7 \pm 2.3$ & $23.4 \pm 0.5$ & - \\
\hline M-4 & Maize & Pakistan & Azospirillum sp. & $8.9 \pm 0.9$ & $125 \pm 1$ & - \\
\hline M-8 & Maize & Pakistan & Azospirillum sp. & $3.2 \pm 0.4$ & $49 \pm 1$ & - \\
\hline W-1 & Wheat & Pakistan & Azospirillum sp. & $3.5 \pm 0.1$ & $63.2 \pm 0.5$ & - \\
\hline $\mathrm{Wb}-3^{\mathrm{D}}$ & Wheat & Pakistan & A. brasilense & $16.1 \pm 1.7$ & $215.2 \pm 15$ & - \\
\hline $\mathrm{N}-4^{\mathrm{D}}$ & Rice & Pakistan & A. lipoferum & $6.3 \pm 1$ & $237.4 \pm 2.5$ & - \\
\hline $\mathrm{JCM}-1224^{\mathrm{D}}$ & Maize & Brazil & A. brasilense & $18.5 \pm 1.6$ & $210.3 \pm 0.6$ & - \\
\hline $\mathrm{JCM}-1270^{\mathrm{D}}$ & Grass $^{\mathrm{C}}$ & Brazil & A. lipoferum & $15.2 \pm 0.8$ & $556.8 \pm 8.7$ & - \\
\hline
\end{tabular}

A Tentative identification based on morphological characteristics.

$\mathrm{B}$ The results of IAA, ARA and $\mathrm{P}$ are an average of three replicates \pm standard deviation.

C Digitaria decumbens.

D Reference strains of Azospirillum brasilense and Azospirillum lipoferum.

${ }^{\text {E }}$ No clear zone formed around bacterial colonies on Pikovskaia's medium containing tricalcium phosphate.

on water-agar (1.5\% agar) plates and one-week-old contamination-free wheat seedlings were transplanted into soil samples collected from Indonesia, Mongolia and Pakistan. The plants were harvested after three weeks and roots were thoroughly washed with sterile water to remove adhering soil. One-gram root pieces were homogenized in $10 \mathrm{~mL}$ of sterile water and serial dilutions were prepared. These dilutions were used to inoculate $\mathrm{N}$-free combined carbon medium (Rennie, 1981) and $\mathrm{N}$-free malate medium (Okon et al., 1977) and incubated at $30 \pm 1{ }^{\circ} \mathrm{C}$. The vials showing bacterial growth and acetylene reduction activity were used to inoculate plates of the same solid media to obtain pure colonies.

The bacterial isolates were grown in Luria Bertani medium with shaking at $30 \pm 1{ }^{\circ} \mathrm{C}$ (Yasmin et al., 2004) and studied for mean generation time (Hafeez et al., 1995) and Gram reaction (Vincent, 1970). The morphological and cultural characteristics of the bacterial strains were studied by light microscopy (Gopala, 1967).

\subsubsection{Bacterial strains}

Out of the seventeen bacterial strains used in the present study, five were isolated from Indonesian soils, five from Mongolian soils and three from Pakistani soils. Bacterial strains Azospirillum brasilense JCM-1224 (ATCC 29145) and A. lipoferum JCM-1270 (ATCC 29709) were obtained from Brazil (Tarrand et al., 1978)., and A. brasilense Wb-3 and A. lipoferum N-4 were obtained from Pakistan (Hassan et al., 1998) (Tab. I).

\subsubsection{Phosphate solubilization}

A single colony of bacterial culture grown on Luria Bertani medium was streaked onto Pikovskaia's medium containing tricalcium phosphate (Pikovskaia, 1948) and incubated at $30 \pm 1{ }^{\circ} \mathrm{C}$ for $7-10$ days. The plates were observed for Clear P-zone formation around the colonies. Quantification of available phosphorus solubilized by the bacterial isolate was quantified by the phospho-molybdate blue color method (Gull et al., 2004). Fresh bacterial culture was grown in Pikovskaia broth on a rotary shaker for 12 days at $24 \pm 1{ }^{\circ} \mathrm{C}$. The suspension was centrifuged at $6000 \times g$ for 15 minutes. The supernatant was decanted and filtered, and the $\mathrm{pH}$ of the sample was analyzed. The available phosphorus was determined at $882 \mathrm{~nm}$ using a spectrophotometer and calibrated with a standard phosphate curve.

\subsubsection{Acetylene reduction assay}

Nitrogenase activity was measured by acetylene reduction assay (Hardy et al., 1968). Pure bacterial colonies were inoculated onto $\mathrm{N}$-free combined carbon medium (Rennie, 1981) in vials and incubated at $30 \pm 1{ }^{\circ} \mathrm{C}$ for $2-3$ days. Acetylene $(10 \%$ $\mathrm{v} / \mathrm{v})$ was injected into the vials. After incubation for $1 \mathrm{~h}$ at room temperature, gas samples $(100 \mu \mathrm{L})$ were analyzed on a gas chromatograph (Thermoquest, Trace G.C, Model K, Rodono, Milan, Italy) equipped with a Porapak Q column and a $\mathrm{H}_{2^{-}}$ flame ionization detector. $\mathrm{H}_{2}$ gas was provided by a $\mathrm{H}_{2}$ generator at $80 \mathrm{~mL} / \mathrm{min}$ (75322, Whatman Incorporation, Haverhill, 
MA, USA) and $\mathrm{N}_{2}$ gas was supplied as a carrier gas at $50 \mathrm{~mL} /$ min (76-94-220, Bolston, Haverhill, MA 01835, USA) to the gas chromatograph. The detector was maintained at $250{ }^{\circ} \mathrm{C}$ and injector at $100{ }^{\circ} \mathrm{C}$.

\subsubsection{Indole-3-acetic acid production}

For the detection and quantification of indole-3-acetic acid production by the bacterial isolates, cultures were grown in Okon's malate medium (Okon et al., 1977). Tryptophan $(100 \mathrm{mg} / \mathrm{L})$ was added as the precursor of indole-3-acetic acid. After one week of growth, qualitative estimations of indole-3acetic acid were performed by $\mathrm{Fe}-\mathrm{HClO}_{4}$ and $\mathrm{Fe}-\mathrm{H}_{2} \mathrm{SO}_{4}$ reagents. The ethyl acetate oxidation method was used for a quantitative estimation of indole-3-acetic acid by HPLC using Turbochom software (Perkin Elmer, USA) (Hameed et al., 2004).

\subsubsection{Utilization of carbon sources}

The bacterial isolates were grown in combined carbon medium $(25 \mathrm{~mL})$, containing different sugars; maltose, galactose, glucose, mannitol and sucrose, to a final concentration of $1 \%(\mathrm{w} / \mathrm{v})$ as carbon sources. All strains were streaked in triplicate and incubated at $30 \pm 1{ }^{\circ} \mathrm{C}$. The presence or absence of growth was observed after 3-5 days of incubation (Hafeez et al., 1995).

\subsubsection{Siderophore production}

Siderophore production by the isolate $8 \mathrm{~N}-4$ was detected using the universal chrome azurol ' $\mathrm{S}$ ' assay as described by (Schwyn and Neilands, 1987). Chrome azurol 'S' plates were spotted with single colony from cultures grown overnight and incubated at $28 \pm 2{ }^{\circ} \mathrm{C}$ for $72 \mathrm{~h}$ (Sharma and Johri, 2003). The amount of siderophore produced was measured as described by Liles et al. (2000).

\subsubsection{Effect of inoculated bacterial isolates on wheat}

Seeds of wheat var. Orkhon received from Mongolia were surface-sterilized with $0.1 \%$ mercuric chloride for five minutes and then washed three times with sterile water. The seeds were germinated on water-agar (1.5\% agar) plates and one-week-old contamination-free wheat seedlings were transplanted into sterilized plastic pots $(12 \times 6.45 \mathrm{~cm})$ containing $30 \mathrm{~g}$ of sterilized vermiculite. Each pot was supplied with $1 / 4$ strength $\mathrm{N}$-free Hoagland solution as nutrient source. Seedlings were transplanted at the rate of 3 seedlings per pot. For inoculation of the plants, bacterial cultures were grown in LB broth for $16 \mathrm{~h}$ at $30 \pm 1{ }^{\circ} \mathrm{C}$. The cells were pelleted by centrifugation at $6000 \times$ $\mathrm{g}$ for $5 \mathrm{~min}$, washed and resuspended in sterile water. The plants were inoculated with $1 \mathrm{~mL}$ of bacterial suspension at a final concentration of $10^{6}-10^{7} \mathrm{cell} / \mathrm{mL}$. The experiment was laid out in a complete randomized block design consisting of three replicates of three plants for each treatment. The non-inoculated plants with and without $\mathrm{N}$ were used as controls. For N-containing non-inoculated plants, $\mathrm{KNO}_{3}(0.05 \%)$ was added, giving a $\mathrm{N}$ concentration of $70 \mu \mathrm{g} / \mathrm{mL}$. Plants were kept in a growth room at $28 \pm 2{ }^{\circ} \mathrm{C}$ during the day, and $25 \pm 2{ }^{\circ} \mathrm{C}$ at night for 6 weeks. At the time of harvesting, root area and root length of the plants were measured with the Root Image Analysis program (Washington State University Research Foundation,
Washington State University, USA). The plants were dried in an oven at $70{ }^{\circ} \mathrm{C}$ until no change in weight was noted. The dry weight of roots and shoots was recorded. Total nitrogen contents of the plants were determined by the Kjeldahl method (Bremner, 1965). Total P of plants was determined colorimetrically by the molybdophosphate method (Murphy and Riley, 1962).

The results of the measurements were subjected to analysis of variance, and significance at the $5 \%$ level was tested by Duncan's multiple range test using a computer software program of M Stat-C. Mean values and the standard error were calculated and the data were analyzed by randomized complete block design.

\subsubsection{RAPD amplification and analysis}

Bacterial strains were grown in Luria Bertani broth for $24 \mathrm{~h}$ with shaking at $30 \pm 1{ }^{\circ} \mathrm{C}$. Cells were centrifuged in the $\log$ phase at $6000 \times g$ for 10 minutes at $4 \pm 1{ }^{\circ} \mathrm{C}$. Total genomic DNA was extracted from the isolates (Sambrook et al., 1989) and quantified by a fluorometer (Hoefer DyNA Quant TM200, San Francisco, USA).

Poymerase chain reaction (PCR) was conducted as reported by Hameed et al. (2004) and Williams et al. (1990). Of the 60 random decamer primers used, 15 were of OPA series (OPA1 to OPA15), 10 of OPB series (OPB5, OPB7, OPB8, OPB9, OPB10, OPB12, OPB14, OPB15, OPB16 and OPB 20), 15 of OPC series (OPC1 to OPC15), 10 of OPJ series (OPJ11 to OPJ20) and 10 of OPR series (OPR1 to OPR10) (Operon Technologies Inc. USA).

Amplification profiles of the 17 strains were compared with each other and bands of DNA fragments were scored as present (1) or absent (0). The RAPD results were a consensus of at least two replications. The data of the primers were used to estimate the genetic similarity on the basis of the number of shared amplification products (Nei and Li, 1979). A dendrogram based on similarity coefficients was generated by using the unweighted pair group of arithmetic means.

\subsubsection{Analysis of 16S rRNA gene sequence}

The complete $1.5 \mathrm{~Kb} 16 \mathrm{~S}$ rRNA region (E. coli positions 8 to 1526$)$ of an isolate $8 \mathrm{~N}-4$ was amplified using primers 616 $(50 \mathrm{pmol} / \mu \mathrm{L})$ as forward primer $\left(5^{\prime}-3^{\prime}:\right.$ AGA GTT TGA TYM TGG CTC AG) and $630(50 \mathrm{pmol} / \mu \mathrm{L})$ as reverse primer $\left(5^{\prime}-\right.$ 3’: CAK AAA GGA GGT GAT CC) (Steidle et al., 2001). The PCR product was cloned into the vector TOPO $\mathrm{R}$ using the TOPO TA cloning kit (Invitrogen) and ligation products were transformed into chemically competent E. coli TOP10 cells, using the material and protocols supplied with the vector. Plasmid DNA was isolated from positive clones using the NucleoSpin R Plasmid kit (Macherey-Nagel, Germany). The plasmids were analyzed by restriction analysis to confirm the presence and correct orientation of the insert. Each $2 \mu \mathrm{L}$ plasmid was restricted with $0.2 \mu \mathrm{L}$ of ECO R1 enzyme by adding $0.2 \mu \mathrm{L}$ of ECO R1 $10 \mathrm{X}$ buffer at $\mathrm{O}^{+}$and $6.8 \mu \mathrm{L}$ of sterile deionized distilled waster. The plasmid suspension was incubated at $30{ }^{\circ} \mathrm{C}$ in an oven for 3 hours. The restriction with ECOR 1 enzyme was analyzed on $1 \%$ agarose gel. The 16S rRNA sequence of isolate $8 \mathrm{~N}-4$ was determined commercially by 
DSMZ, Braunschweig, Germany and was deposited in GenBank under accession number AY548949.

\section{RESULTS AND DISCUSSION}

The scope of this investigation was to characterize the genetic and physiological variation of rhizosphere isolates from different crops, i.e. maize, wheat, rice and a grass (D. decumbens) species. These crops harbor diverse bacterial populations, among which several bacterial species may have the potential to support plant growth and increase the crop yield for sustainable agriculture (Dobereiner et al., 1995).

\subsection{Morphological and physiological characterizations of bacterial strains}

PGPB were characterized on the basis of their morphological and cultural characteristics as well as their ability to produce growth hormones, fix nitrogen, solubilize phosphate (Tab. I) and utilize different carbon sources. All strains were Gramnegative except $8 \mathrm{~N}-4$ and were fast-growing motile rods of different sizes. The colonies produced were circular, translucent, opaque, white, off-white and yellow with smooth or irregular margins. The variation in morphological characteristics showed that morphological characteristics did not have spatial limitations, but were generally adapted to the different ecological or environmental conditions of the study areas.

All isolates were able to fix nitrogen with substantial variation (20.3-556.8 $\mathrm{nmol}$ acetylene reduced/h/vial) except AZ-B and AZ-S, isolated from a rice rhizosphere in Indonesia. Thus, free-living and associative nitrogen-fixing bacteria present on the roots might be contributing nitrogen to these plants. All bacteria in the study, irrespective of region and host, were able to produce indole acetic acid ranging from $0.8-42.1 \mu \mathrm{g} / \mathrm{mL}$ (Tab. I). Isolate $8 \mathrm{~N}-4$ produced the highest amount of indole acetic acid $(42.1 \mu \mathrm{g} / \mathrm{mL})$, followed by MST-4.1 $(37.7 \mu \mathrm{g} / \mathrm{mL})$. It has been reported that Azospirillum, Azotobacter, Pseudomonas and many other genera are phytohormone-producing (Bai et al., 2002; Patten and Glick, 2002; Pandey and Palni, 1998; Bashan and Holguin, 1997; Reynders and Vlassak, 1979; Tien et al., 1979; Barea and Brawn, 1974) and nitrogen-fixing microorganisms (Glick, 1995). This may be an indication of the potential of the environmental conditions in the sampled areas of Indonesia and Mongolia to harbor growth hormone-producing PGPBs.

Another important characteristic for inoculant development, shown by only one isolate, $8 \mathrm{~N}-4$, was $\mathrm{P}$ solubilization on Pikovskaya's medium., This indicated the possession of mineral phosphate solubilization function by this strain. Quantitative estimation of phosphate solubilization by isolate $8 \mathrm{~N}-4$ was found to be $188.7 \mu \mathrm{g} / \mathrm{mL}$. A decrease in $\mathrm{pH}$ of Pikovskaia's broth from 7-4.8 showed the activity of phosphate-solubilizing bacteria. No other isolate was able to solubilize phosphates (Tab. I). P is mostly present as an insoluble form of calcium phosphates in soils with high $\mathrm{pH}(>7.5)$; therefore, calcium triphosphate is usually used as a substrate for $\mathrm{P}$ solubilization (Sikander et al., 1998). It has been observed in this study that most of the PGPB strains isolated from cereals did not solubilize phosphates. However, the organisms isolated from the rhizosphere of legumes have been found to be more efficient at solubilizing phosphates than those from the non-rhizosphere or from the root zone of non-legumes (Gull et al., 2004; Hameed et al., 2004; Gopala, 1967; Sobieszczanski, 1961). Therefore, there is a need to isolate and select more phosphate-solubilizing microorganisms to be used in multistrain inocula for cereals (Bashan and Holguin, 1997).

Carbon source utilization tests showed that most of the strains isolated from maize and wheat tended to use a wider variety of carbohydrates than those isolated from rice. All the bacteria isolated from wheat and maize soils of Brazil, Indonesia, Mongolia and Pakistan utilized all the carbon sources tested, i.e. glucose, galactose, maltose, mannitol and sucrose. Strains AZ-B and AZ-S isolated from rice under the same soil conditions utilized the same carbon sources. Isolates Bt.J No.8 and LS-1 isolated from maize roots under similar acid soil conditions of Indonesia utilized the same carbon sources. Many authors have used and recommended carbon source utilization as a helpful tool to characterize the isolates (Hafeez et al., 1995; Moawad and Bohlool, 1993).

Isolate $8 \mathrm{~N}-4$ produced an orange halo zone on a blue background showing a positive chrome azurol ' $S$ ' test, indicating siderophore production by this bacteria. The amount of siderophores produced by $8 \mathrm{~N}-4$ was quantified as $0.3 \mathrm{mg} / \mathrm{L}$. Disease reduction involving siderophore-mediated competition is generally believed to be one of the antagonistic interactions that result in the exclusion of fungal pathogens from the rhizosphere due to reduction in the availability of iron for spore germination and hyphal growth (Rachid and Ahmed, 2005).

The isolates, from wheat grown in Mongolian soil, showed beneficial effects on root area, root length and dry weight of root and shoot. All of the growth parameters studied and quantification of total $\mathrm{N}$ and $\mathrm{P}$ contents in shoot samples showed that the effect of bacterial inoculation was more prominent with isolate $8 \mathrm{~N}-4$ as compared with the other isolates tested and the controls (Tab. II).

The importance of bacterial isolate $8 \mathrm{~N}-4$ is particularly significant regarding its acetylene reduction assay, indole acetic acid, P solubilization, siderophore production (Tab. I) and its beneficial effects on plant growth and nitrogen fixation (Tab. II). Therefore, bacterial isolate $8 \mathrm{~N}-4$ is a potential PGPB strain and, after further testing under field conditions, may be useful for development as an inoculant for biofertilizer production for wheat. It is well documented that application of bacterial inoculants as biofertilizers has resulted in improved growth and increased yield of cereal crops (Vessey, 2003).

\subsection{Random amplified polymorphic DNA (RAPD) analysis}

It has been observed that although biochemical markers may help in differentiating the genera, they are not sufficient as the sole parameter to estimate the real extent of diversity. RAPD analysis may be used as a quick and reliable alternative for establishing differences among different species as well as among strains of the same species. As evident from RAPD analysis, the variation within the groups was also quite large and 
Table II. Effect of inoculated PGPBs isolated from Mongolia on root length, root area, root dry weight, shoot dry weight, and P and N contents of wheat var. Orkhon.

\begin{tabular}{|c|c|c|c|c|c|c|}
\hline Treatments & $\begin{array}{l}\text { Root } \\
\text { length } \\
(\mathrm{mm})\end{array}$ & $\begin{array}{c}\text { Root } \\
\text { area } \\
\left(\mathrm{mm}^{2}\right)\end{array}$ & $\begin{array}{c}\text { Root } \\
\text { dry wt. } \\
\text { (g/plant) }\end{array}$ & $\begin{array}{l}\text { Shoot } \\
\text { dry wt. } \\
\text { (g/plant) }\end{array}$ & $\begin{array}{c}\mathrm{N} \\
(\mu \mathrm{g} / \mathrm{g})\end{array}$ & $\begin{array}{c}\mathrm{P} \\
(\mu \mathrm{g} / \mathrm{g})\end{array}$ \\
\hline $8 \mathrm{~N}-4$ & $102.0 \mathrm{a}$ & $15.1 \mathrm{a}$ & $0.04 \mathrm{a}$ & $0.31 \mathrm{a}$ & $9.6 \mathrm{a}$ & $8.2 \mathrm{a}$ \\
\hline $8 \mathrm{~N}-2$ & $90.1 \mathrm{~b}$ & $13.0 \mathrm{~b}$ & $0.031 b$ & $0.23 \mathrm{c}$ & $8.2 \mathrm{bc}$ & $7.4 \mathrm{abc}$ \\
\hline $24 \mathrm{~N}-2$ & $74.8 \mathrm{~d}$ & $9.2 \mathrm{de}$ & $0.012 \mathrm{c}$ & $0.20 \mathrm{~d}$ & $7.5 \mathrm{~cd}$ & $7.1 \mathrm{bcd}$ \\
\hline MST-6.1 & $85.1 \mathrm{c}$ & $11.2 \mathrm{c}$ & $0.012 \mathrm{c}$ & $0.24 b c$ & $7.9 \mathrm{bcd}$ & 7.3abcd \\
\hline MST-4.1 & $64.3 \mathrm{e}$ & $8.2 \mathrm{e}$ & $0.012 \mathrm{c}$ & $0.20 \mathrm{~d}$ & $7.2 \mathrm{~d}$ & $6.8 \mathrm{cde}$ \\
\hline Control $^{1}$ & $49.0 \mathrm{f}$ & 5.1f & $0.010 \mathrm{c}$ & $0.17 \mathrm{e}$ & $5.4 \mathrm{e}$ & $5.9 \mathrm{e}$ \\
\hline Control $^{2}$ & $92.3 \mathrm{~b}$ & $10.0 \mathrm{~d}$ & $0.030 \mathrm{~b}$ & $0.25 b$ & $8.8 \mathrm{~b}$ & $7.9 \mathrm{ab}$ \\
\hline
\end{tabular}

${ }_{1}^{1}$ Control: non-inoculated without $\mathrm{N}$.

2 Control: non-inoculated without

Means are the average of three replicates with three plants each. Means followed by the same letter are not significantly different at $P=0.05$ according to Duncan's multiple range test.

helpful in defining not only sub-groups but also in defining the distances of isolates from standard strains of the PGPBs used.

RAPD analysis was performed using 60 different random primers to establish the relationship between the isolates and reference PGPB. A total of 832 DNA fragments were amplified, with an average of approximately 14 bands per primer. Primer OPJ-18 produced the maximum number of bands (24) while primer OPB-8 produced the minimum number of bands (9). The fragments amplified were in the range of 0.4 to $4 \mathrm{~Kb}$. The genetic similarities ranged from 19.2-90\%. Moreover, a dendrogram showed that the strains were clustered into four groups (Fig. 2). Bt.J No. 8 and LS-1 clustered together, indicating in $91 \%$ of their significant amplified DNA bands, corresponding to isolated strains from the same host and soil of Indonesia. On the other hand, isolate $07-\mathrm{K}$ showed a relatedness in $87 \%$ of its significant bands with the isolates Bt.J No.8 and LS-1 (Fig. 1). The bacterial isolates Bt.J No.8, 07-K and LS-1 may belong to the same genus and species (Tab. I), although DNA-DNA hybridization and further descriptions are required for accurate identification. All the PGPBs isolated from the wheat soil of Mongolia fell into cluster 'B', with similarity ranging from $32-41 \%$.

Reference strain A. lipoferum N-4 from a rice soil of Pakistan, forming a sub-group with cluster "B", fell separately from all other strains isolated from wheat and maize roots. Reference strains A. brasilense JCM-1224 and A. lipoferum JCM-1270 obtained from Brazil were clustered together and showed $35 \%$ genetic homology, while 24\% homology was observed between $A$. brasilense $\mathrm{Wb}-3$ and A. lipoferum $\mathrm{N}-4$ obtained from Pakistan. Homology among the strains of the same genus, but of different species recovered from the same region, ranged from 24-35\%. Two strains of A. brasilense, Wb-3 and JCM1224 , of the same species and genus from wheat and maize, respectively, recovered from different regions showed $59 \%$ homology, while the other two strains of A. lipoferum, N-4 and JCM-1270, from rice and Digitaria decumbens, respectively, recovered from different regions showed $20 \%$ homology. None of the PGPBs isolated from Indonesia clustered with PGPBs from Mongolian soils (Fig. 2).
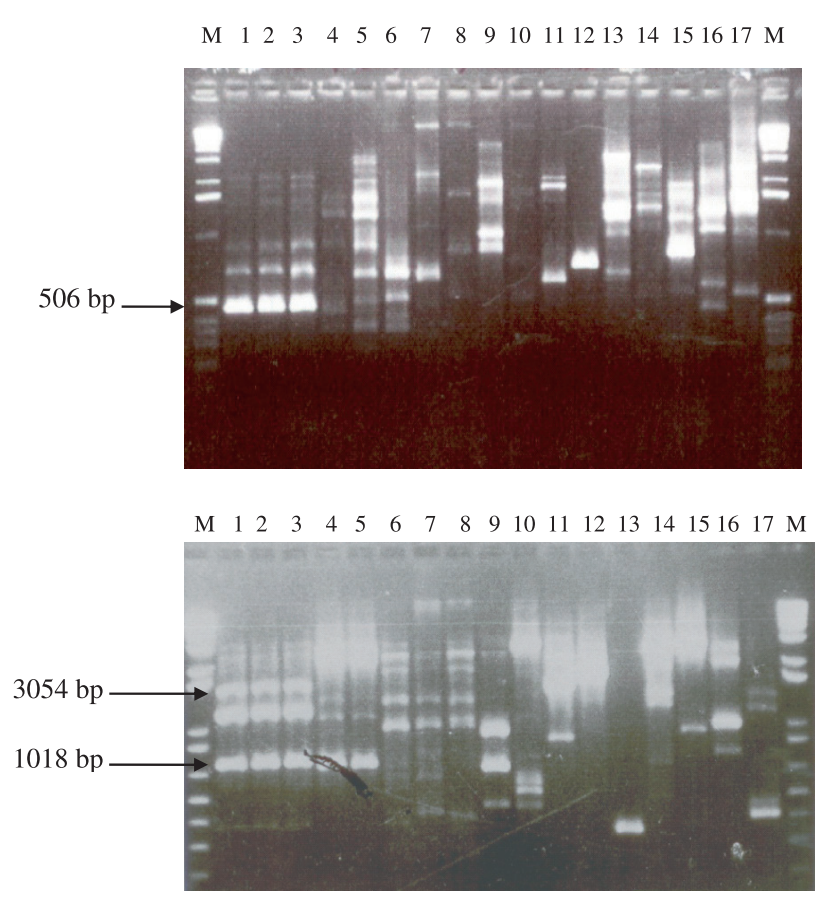

Figure 1. RAPD patterns of seventeen PGPB strains isolated from geographically different regions showed variation in the band profiles for each primer. Amplification products of the same size from different strains represented homologous sequences shared by these isolates. Lane/strains: M/1 Kb ladder, 1/ 07-K, 2/ Bt.J No.8, 3/ LS-1, 4/ AZ-B, 5/ AZ-S, 6/ Wb-3, 7/ W-1, 8/ M-4, 9/ M-8, 10/ N-4, 11/ JCM 1224, 12/ JCM 1270, 13/ 8N-4, 14/ Mst.4.1, 15/ 6.1, 16/ 8N-4, 17/ 24-N2. (a) RAPD patterns with primer OPB-7. (b) RAPD patterns with primer OPC-8.

Wheat isolate $\mathrm{W}-1$ showed significant similarity (64\%) to the reference wheat strain $A$. brasilense $\mathrm{Wb}-3$, indicating that this isolate may belong to Azospirillum. The previous estimates of variation showed $80-90 \%$ polymorphism between gene pools, 50-60\% polymorphism between races of the same gene pool and 20-30\% polymorphism between genotypes of the 


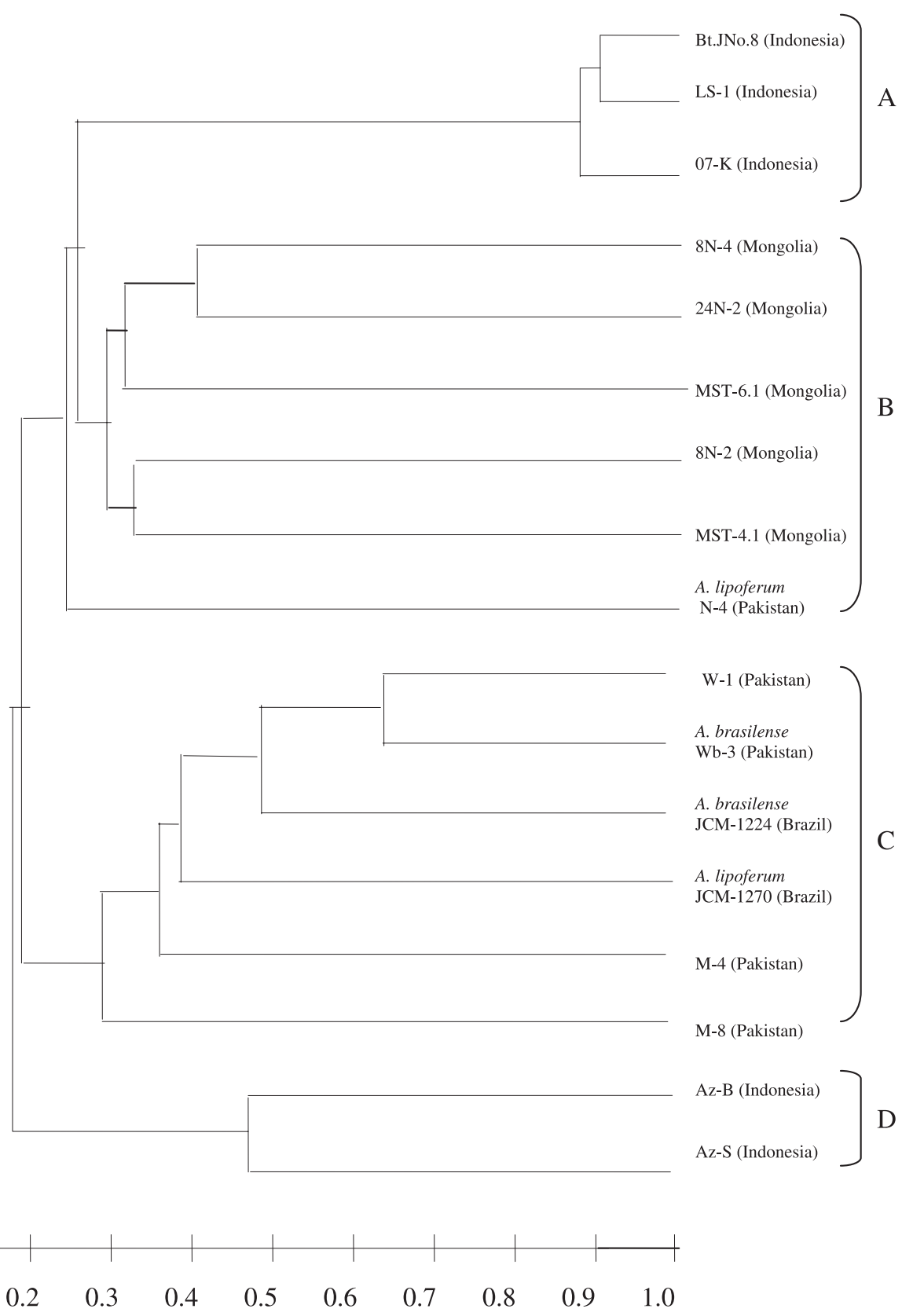

Figure 2. Dendrogram showing genetic relationship of seventeen PGPBs isolated from the soils obtained from geographically different regions as determined by RAPD analysis. Isolates from Indonesia were found to be more diverse as they were scattered throughout the dendrogram compared with the other isolates from Brazil, Mongolia and Pakistan, most of which clustered together in the same similarity group.

same race (Yonghe et al., 1998). A. lipoferum $\mathrm{N}-4$ was isolated from rice but showed more genetic homology to the wheat isolates. It may be correlated with previous data that showed that it is more effective at promoting growth of wheat and had a moderate effect on rice (Malik et al., 1998). The genetic diversity estimates were higher between PGPB strains recovered from different regions than between PGPB isolates from different hosts, confirming the reports of Gomes et al. (2001) and Saleena et al. (2001).
RAPD profiles resolved differences on a much finer scale between isolates. This rapid selection system by RAPD may be a very useful tool for excluding similar bacterial isolates encountered during screening.

\section{3. $16 \mathrm{~S}$ rRNA sequence analysis}

The complete $16 \mathrm{~S}$ rRNA sequence analysis of strain $8 \mathrm{~N}-4$ (Accession number AY548949) showed 99.37\% homology with Bacillus pumilus. 


\section{CONCLUSION}

A set of seventeen PGPB strains was characterized based on metabolic activities regarded as biofertilizer traits: nitrogenfixing ability, indole acetic acid production, siderophore production and phosphate solubilization. The isolates that tested positive for any of the evaluated traits were analyzed by polymerase chain reaction (PCR-RAPDs) to reduce genetic redundancy by selecting genetically different bacterial strains. Thus the characterization and screening of PGPB has helped in the selection of $8 \mathrm{~N}-4$ as a potent strain in stimulating growth promotion and yield increase in wheat, as well as having the potential to be used as a biocontrol agent. Presently, there is little information on the occurrence of PGPBs in Mongolia and their potential to be used for the production of inoculants. PGPBs harbored by such unexplored environments may be looked upon as being wild types showing natural variability. Mongolian strain 8N-4, identified as Bacillus pumilus, deposited in the DSMZ German culture collection with accession no. DSM 16528, may be used as a biofertilizer component for wheat variety Orkhon in Mongolia. Furthermore, the results of this study have implications for biotechnological exploitation of bacterial inocula in field applications.

Acknowledgements: Financial support of this research was partly provided by FAO/IAEA TC Project No. PAK/5/037, IAEA project No. INS/00016P, IAEA project No. MON/010 and IDB project in the Establishment of Biofertilizer Resource Center (BIRCEN). We are thankful to Ms. Dorjyn Naranchim and Ms. Bongosurengyn Delgermaa from the Mongolian Agricultural University, Plant Science and Agricultural Research Institute, Darkhan, Mongolia for bacterial isolations. Thanks are due to Dr. Ghulam Rasool for his technical assistance and Dr. Farooq Latif for his help with detecting phytohormones by HPLC.

\section{REFERENCES}

Bai Y., Aoust D., Smith F.D.L., Driscoll B.T. (2002) Isolation of plantgrowth promoting Bacillus strains from soybean root nodules, Can. J. Microbiol. 48, 230-238.

Barea J.M., Brawn M.E. (1974) Effect on plant growth produced by Azotobacter paspali related to synthesis of plant growth regulating substances, J. Appl. Bacteriol. 37, 583-593.

Bashan Y., Holguin G. (1997) Azospirillum - plant relationships: environmental and physiological advances (1990-1996), Can. J. Microbiol. 43, 103-121.

Bremner J.M. (1965) Total nitrogen, in: Black C.A. (Ed.), Agronomy 9, $1149-1178$.

Bull A.T., Goodfellow M., Slater J.H. (1992) Biodiversity as a source of innovation in biotechnology, Ann. Rev. Microbiol. 46, 219-52.

Dobereiner J., Marriel E., Nera M. (1976) Ecological distribution of Spirillum lipoferum Beijernck, Can. J. Microbiol. 22, 1464-1473.

Dobereiner J., Baldani V.L.D., Resis V.M. (1995) Endophytic occurrence of diazotrophic bacteria in non-leguminous crops, in: Ferdrick I., Gallo M., Vanderleyden J., Zamarocy M. (Eds.), Azospirillum VI and related microorganisms, Berlin, Springer Verlag, pp. 3-14.

Glick B.R. (1995) The enhancement of growth free-living bacteria, Can. J. Microbiol. 41, 109-117.

Gomes N.C.M., Heuerj H., Schonfld R.C., Mendonca-Hagler L., Smalla K. (2001) Bacterial diversity of the rhizosphere of maize (Zea mays) grown in tropical soil studied by temperature gradient gel electrophoresis, Plant Soil 232, 167-180.

Gopala K.A. (1967) Effect of bacterisation of rice seeds on the rhizosphere micro flora and plant growth, Indian J. Microbiol. 7, 21-28.

Gull M., Hafeez F.Y., Saleem M., Malik K.A. (2004) Phosphate-uptake and growth promotion of chickpea (Cicer arietinum L.) by co-inoculation of mineral phosphate solubilizing bacteria and a mixed rhizobial culture, Aust. J. Exp. Agr. 44, 1-6.

Hafeez F.Y., Asad S., Ahmad T., Malik K.A. (1995) Host specificity and characterization of fast growing rhizobia from Macroptilium atropurpureum cv. siratro in Pakistan, Soil Biol. Biochem. 27, 729-733.

Hameed S., Yasmin S., Malik K.A., Zafar Y., Hafeez F.Y. (2004) Rhizobium, Bradyrhizobium and Agrobacterium strains isolated from cultivated legumes, Biol. Fertil. Soils 39, 179-185.

Hardy R.W.F., Holsten R.D., Jackson E.K., Burns R.E. (1968) The acetylene-ethylene assay for nitrogen fixation: Laboratory and field evaluation, Plasmid 14, 47-52.

Hartmann A., Amarger N. (1991) Genenotypic diversity of an indigenous Rhizobium meliloti field population assessed by plasmid profiles, DNA finger printing and insertion sequence typing, Can. J. Microbiol. 37, 600-608.

Hassan U., Mirza M.S., Menhaz S., Rasul S., Malik K.A. (1998) Isolation and identification of diazotrophic bacteria from rice, wheat and kallar grass, in: Malik K.A., Mirza M.S., Ladha J.K. (Eds.), Nitrogen fixation with non-legumes, Kluwer Academic Publishers, Printed in Great Britain, pp. 197-205.

Liles M.R., Scheel T.A., Cianciotto N.P. (2000) Discovery of a nonclassical siderophore, legiobactin produced by strains of Legionella pneumophila, J. Bacteriol. 182, 749-757.

Malik K.A., Rasul G., Hassan U., Menhaz S., Ashraf M. (1998) Role of $\mathrm{N}_{2}$-fixing and growth hormone producing bacteria in improving growth of wheat and rice, in: Malik K.A., Mirza M.S., Ladha J.K. (Eds.), Nitrogen fixation with non-legumes, Kluwer Academic Publishers, Printed in Great Britain, pp. 197-205.

Moawad H., Bohlool B.B. (1993) Characterization of rhizobia from Leucaena, World J. Microbiol. Biotech. 8, 387-392.

Murphy J., Riley J.P. (1962) A modified single method for the determination of phosphate in natural waters, Anal. Chim. Acta 27, 31-36.

Muyzer G., Smalla K. (1998) Application of denaturing gradient gel electrophoresis (DGGE) and temperature gradient gel electrophoresis (TGGE) in microbial ecology, Anton. Leeuw. Int. J. G. 73, 127-141.

Nei N., Li W. (1979) Mathematical model for studying genetic variation in terms of restriction endonucleases, Proc. Natl Acad. Sci. (USA) 76, 5269-5273.

Okon Y., Albercht S.L., Burris R.H. (1977) Methods for growing Spirillum lipoferum and for counting it in pure culture and in association with plants, Appl. Environ. Microbiol. 33, 85-88.

Pandey A., Palni L.M.S. (1998) Isolation of Pseudomonas corrugate from Sikkim Himalaya, World J. Microbiol. Biotech. 14, 411-413.

Patten C.L., Glick B.R. (2002) The role of bacterial indole acetic acid in the development of the host plant root system, Appl. Environ. Microbiol. 68, 3795-3801.

Pikovskaia R.I. (1948) Metabolisation of phosphorus in soil in connection with vital activity of some microbial species, Microbiologiya 17, 362-370.

Raaijmakers J.M., Weller D.M. (2001) Exploiting genotypic diversity of 2, 4-Diacetylphloroglucinol producing Pseudomonas spp. Characterization of superior root-colonizing $P$. fluorescens strain Q8r1-96, Appl. Environ. Microbiol. 67, 2554-25554. 
Reed E.L.M., Glick B.R. (2004) Applications of free living plant growthpromoting rhizobacteria, Anton. Leeuw. Int. J. G. 86, 1-25.

Rennie R.J. (1981) A single medium for the isolation of nitrogen fixing bacteria, Can. J. Microbiol. 27, 8-14.

Reynders L., Vlassak K. (1979) Conversion of tryptophan to indole acetic acid by Azospirillum brasilense, Soil Biol. Biochem. 11, 557-558.

Rachid D., Ahmed B. (2005) Effect of iron and growth inhibitors on siderophores production by Pseudomonas fluorescence, Afr. J. Biotech. 4, 697-702.

Salamone I.E.G., Hynes R.K., Nelson L.M. (2001) Cytokinin production by plant growth promoting rhizobacteria and selected mutants, Can. J. Microbiol. 47, 404-411.

Saleena L.M., Loganathan P., Rangarajan S. (2001) Genetic diversity and relationship between Bradyrhizobium strains isolated from blackgram and cowpea, Biol. Fertil. Soils 34, 276-281.

Sambrook J., Fritch E.F., Maniatis T. (1989) Molecular cloning: A laboratory Manual, Cold Spring Harbor Laboratory Press, USA.

Santos P.E.D.L., Bustillos-Cristales R., Caballero-Mellado J. (2001) Burkholderia, a genus rich in plant-associated nitrogen fixers with environmental and geographic distribution, Appl. Environ. Microbiol. 67, 2790-2798.

Schwyn B., Neilands J.B. (1987) Universal chemical assay for detection and determination of siderophores, Anal. Biochem. 160, 40-47.

Sharma A., Johri B.N. (2003) Growth promoting influence of siderophoreproducing Pseudomonas strains GRP3 and PRS9 in maize (Zea mays L.) under iron limiting conditions, Microbiol. Res. 158, 243248.

Sikandar A., Hamid N., Nagina N., Malik K.A. (1998) Screening of phosphate solubilizing microorganisms using different original and modified culture media, Biologia 44, 110-124.
Sobieszczanski J. (1961) The share of rhizosphere bacteria in mobilizing, transporting and storing phosphorus from the unavailable phosphate, Soils Fertil. 25, 124.

Staley J.T. (1999) Bacterial biodiversity: a time for place, ASM News 65, 681-687.

Steidle A., Sigl K., Schuhegger R., Ihring A., Schmid M., Gantner S., Stoffels M., Riedel K, Givskov M., Anton H., Langebartels C., Eberl L. (2001) Visualization of $N$ - Acylhomoserine Lactonemediated cell-cell communication between bacteria colonizing the tomato rhizosphere, Appl. Environ. Microbiol. 67, 5761-5770.

Tarrand J.J., Krieg N.R., Dobereiner J. (1978) A taxonomic study of the Spirillum lipoferum group, with descriptions of a new genus. Azospirillum gen. nov. and two species, Azospirillum lipoferum (Beijerinck) comb. nov. and Azospirillum brasilense sp. nov, Can. J. Microbiol. 24, 967-980.

Tien T.M., Gaskins M.H., Hubbell D.H. (1979) Plant growth substances produced by Azospirillum brazilense and their effect on the growth of Pearl millet, Appl. Environ. Microbiol. 37, 1016-1024.

Vessey J.K. (2003) Plant growth promoting rhizobacteria as biofertilizers, Plant Soil 255, 571-586.

Vincent J.M. (1970) A manual for the practical study of root nodule bacteria, IBP Handbook, Blackwell, Oxford, p. 15.

Williams J.G.K., Kubelic A.R., Livak K.J., Rafalski J.A., Tingey S.V. (1990) DNA polymorphisms amplified by arbitrary primers are useful as genetic markers, Nucleic Acids Res. 18, 6531-6535.

Yasmin S., Bakar M.A.R., Malik K.A., Hafeez F.Y. (2004) Isolation, characterization and beneficial effects of rice associated PGPB from Zanzibar soils, J. Basic Microbiol. 44, 241-252.

Yonghe B., Michaels T.E., Pauls K.P. (1998) Determination of genetic relationships among Phaseolus vulgaris populations in a conical cross from RAPD markers analysis, Mol. Breeding 4, 395-406.
To access this journal online: www.edpsciences.org 